\title{
MATHEMATICAL MODELS OF REPLACEMENT AND WEARING OF EQUIPMENT
}

\author{
Ya.D. Gelrud, gelrud@mail.ru, \\ A.V.Gollay, alexander@hollay.ru \\ South Ural State University, Chelyabinsk, Russian Federation
}

\begin{abstract}
Resolving issues of effective use of equipment is a one of the most important problem while managing industrial production. Minor and major structuring repairs of the equipment and its replacement are connected with considerable material, labour and financial expenses. Besides, equipment downtimes influence significantly the efficiency of industrial production in general. In the article mathematical models of problems of replacement of the equipment at the determined and stochastic information for a limited and unlimited period are described. Moreover, there is a model of replacement of the equipment which uses the terms of network modelling, also algorithms of dynamic programming are used when modelling a problem of replacement of the equipment. On the basis of the offered models, the generalizing algorithm of the solution of a problem of replacement of the equipment is constructed. Also it is shown that taking a factor of uncertainty at the solution of problems of this class into account is important. The received results can be used to design an optimum strategy of replacement of the equipment at a manufacturing enterprise.

Keywords: equipment, replacement of the equipment, investment, investment policy, dynamic programming, strategy.
\end{abstract}

\section{Introduction}

To ensure high competitiveness of a manufacturing enterprise it is necessary to provide timely upgrade and modernization of the current equipment. The main objectives of the theory of replacement of the equipment are to foresee the necessary expenses and to design the most effective strategy of replacements $[1,2]$.

In this article the generalizing algorithm of the solution of a problem of replacement of the equipment is considered based on the analysis of the available models and algorithms [3-5]. Replacement processes are divided into two classes depending on the equipment type. The first class is connected with the equipment which becomes outdated in use and whose productivity decreases as a result of wearing. Or it becomes outdated as improved machinery (computers, cars, metal-cutting machines, etc.) emerges. During the operation of the outdated equipment there is a growth of production expenses, extension of downtime, increase in repair period, number of refusals, etc. The replacement of the equipment into something new is connected with even vaster expenses. The objective of solving the problem is to define such service life of the equipment at which the effect of the newly purchased equipment exceeds its initial cost. Renting the equipment suggests taking the following reasons into account: the increase in term of lease reduces the rent per unit time and at the same time operational costs increase [6-8].

The second class is connected with the equipment which has random service life (for example, chip elements, light bulbs). While solving these problems, it is necessary to define what equipment should be replaced and in what terms it is necessary to do it to minimize the general expenses. If we replace the equipment only after its breakage, the expenses associated with downtimes increase, but at the same time the costs of upgrade minimize. Whereas the replacement of the equipment before its breakage leads to vast expenses, but low costs of repair work. The basis for the solution of the second class problems is that there is the distribution law of probabilities of the equipment failure depending on the term of its service. At the same time it is necessary to involve the methods of mathematical statistics, besides, when modelling problems of replacement of the equipment we will apply the probability theory, network methods and dynamic programming [9-11]. 


\section{Управление в социально-экономических системах}

\section{Deterministic models of replacement of equipment}

\subsection{Simple model}

Assume that $s_{i}$ is expenses in the $i$ period to purchase and operate the equipment. We will consider only such operational costs which change as service life increases. At the same time we will define interval $n$ after which replacement will be made for the following reasons:

- if the expenses in the following period are less than the average of the previous expenses, it isn't necessary to replace the equipment;

- if the expenses in the following period exceed the average expenses, it is necessary to replace the equipment.

Thus, the following inequalities have to be fulfilled:

$$
\begin{aligned}
& s_{n}<\left(s_{1}+s_{2}+\ldots+s_{n-1}\right) /(n-1), \\
& s_{n+1}>\left(s_{1}+s_{2}+\ldots+s_{n}\right) / n .
\end{aligned}
$$

Example 1. Let the expenses associated with replacement and purchase of the equipment be presented in Table 1.

Expenses associated with replacement and purchase of the equipment

\begin{tabular}{|l|c|c|c|c|c|c|}
\hline Period, $n$ & 1 & 2 & 3 & 4 & 5 & 6 \\
\hline Expenses, $s_{i}$ & 50 & 10 & 20 & 30 & 40 & 50 \\
\hline Average expenses & 50 & 30 & $26.7^{* *}$ & 27.5 & 30 & 33.3 \\
\hline
\end{tabular}

In column 3 average expenses by the right part of formula (1) are calculated. We receive the decision which implies replacement of equipment in period 3 as

$$
s_{3}=20<\left(s_{1}+s_{2}\right) / 2=30, s_{4}=30>\left(s_{1}+s_{2}+s_{3}\right) / 3=26.7 \text {. }
$$

The cost of money changes over time due to a possibility of investing it and receiving income. Therefore it is necessary to carry out calculations with a discounting coefficient. Let $i$ be deposit percent in each period, discounting coefficient being $r=1 /(1+i / 100)$. We replace average expenses into average discounted expenses in (1)-(2):

$$
\begin{aligned}
& s_{n}<\left(s_{1}+s_{2} r+\ldots+s_{n-1} r^{n-2}\right) /\left(1+r+\ldots+r^{n-2}\right), \\
& s_{n+1}>\left(s_{1}+s_{2} r+\ldots+s_{n} r^{n-1}\right) /\left(1+r+\ldots+r^{n-1}\right) .
\end{aligned}
$$

Example 2. Let the expenses of purchase and replacement of equipment be similar to the previous example and $i=5 \%$. The average discounted expenses $(r=0,952)$ are given in the 3 rd column of Table 2 .

\section{Discounted expenses associated with replacement and purchase of equipment}

\begin{tabular}{|l|c|c|c|c|c|c|}
\hline Period, $n$ & 1 & 2 & 3 & 4 & 5 & 6 \\
\hline Expenses, $s_{i}$ & 50 & 10 & 20 & 30 & 40 & 50 \\
\hline Weighted average & 50 & 30.49 & $27.16^{*}$ & 28.82 & 30.02 & 32.96 \\
\hline
\end{tabular}

The decision in this case is replacement of equipment in period 3 as well, since ratios (4)-(5) are fulfilled at $n=3$. Both examples assumed that operational costs of the equipment increase over time.

\subsection{Network model}

Let us introduce a model of replacement of equipment using the language of network modelling. Let us assume that we need to devise a plan to rent the equipment for $\mathrm{n}$ years. We shall consider the event of $i$ as the beginning of year $i(i \leq n)$. Let the expenses value $s_{i j}$ include the rent and the expected maintenance costs of the equipment which at the beginning of year $i$ is leased and replaced at the beginning of year $j$. Then we shall consider arch $(i, j)$ the lease contract of the equipment since 
the beginning of year $i$ until the beginning of year $j$. Thus we have received an oriented acyclic network. The plan of rent has to be made so that to minimize total expenses that, in the network language, corresponds to finding the shortest way in the network from event 1 to $n+1$. Thus, to reduce the problem of renting the equipment to the network model we need to be able to calculate $s_{i j}$ coefficients.

Example 3. Let us assume that maintenance expenses of the equipment in years 1, 2, 3, 4 and 5 amount 1, 3, 6, 10 and 15 respectively. At the same time, let the rent amount 5, 9, 13, 16 and 19 respectively. Besides, every year rent payments increase by 1 i.e. if the equipment is leased at the beginning of the third year for 1, 2 or 3 years, for example, rent will amount 7,11 and 15 respectively. We will tabulate the calculated $\mathrm{s}_{i j}$ coefficients in Table 3 .

Values of $s_{i j}$ coefficients

Table 3

\begin{tabular}{|c|c|c|c|c|c|}
\hline$s_{i j}$ & 2 & 3 & 4 & 5 & 6 \\
\hline 1 & $1+5=6$ & $3+9=12$ & $6+13=19$ & $10+16=26$ & $15+19=34$ \\
\hline 2 & & $1+6=7$ & $3+10=13$ & $6+14=20$ & $10+17=27$ \\
\hline 3 & & & $1+7=8$ & $3+11=14$ & $6+15=21$ \\
\hline 4 & & & & $1+8=9$ & $3+12=15$ \\
\hline 5 & & & & & $1+9=10$ \\
\hline
\end{tabular}

In this example we are devising the plan of rent for 5 years, therefore we have introduced event 6 as the end of year 5. We shall now apply the algorithm of finding the shortest way to the received network (see [1]). Let $y_{i}$ be the minimum value of expenses which is reached upon transition from event $i$ to final event $n+1$.

$$
\begin{aligned}
& y_{6}=0, \\
& y_{5}=\min \left\{s_{56}+y_{6}\right\}=10+0=10, \\
& y_{4}=\min \left\{s_{45}+y_{5}, s_{46}+y_{6}\right\}=\min \{9+10,15\}=15, \\
& y_{3}=\min \left\{s_{34}+y_{4}, s_{35}+y_{5}, s_{36}+y_{6}\right\}=\min \{8+15,14+10,21\}=21, \\
& y_{2}=\min \left\{s_{23}+y_{3}, s_{24}+y_{4}, s_{25}+y_{5}, s_{26}+y_{6}\right\}=\min \{7+21,13+15,20+10,27\}=27, \\
& y_{1}=\min \left\{s_{12}+y_{2}, s_{13}+y_{3}, s_{14}+y_{4}, s_{15}+y_{5}, s_{16}+y_{6}\right\}= \\
& =\min \{6+27,12+21,19+15,26+10,34\}=33 .
\end{aligned}
$$

There are two shortest ways here (1-2-6) and (1-3-6). Thus, we have received two optimum strategies of rent:

1) to sign the contract for a year and to sign the contract for the remained 4 years at the beginning of the second year;

2) at first to sign the contract for two years and to sign the contract for the remained 3 years at the beginning of the third year.

At both options the minimum expenses amount 33 .

Example 4. It is necessary to define a plan of replacement of a machine tool for the next seven years (it will not be required any longer) if the following is known:

a) $p_{t}$ is the cost of a new model in year $t$,

b) $v_{k}$ is the salvage cost of the machine tool after $k$ years of operation,

c) $r_{k}$ is operational costs of the machine tool in year $k$ of its operation.

As well as in the previous example, we shall define events as beginnings of each year. We shall imply arch $(i, j)$ as the decision to replace the machine tool vat the beginning of year $j$ bought at the beginning of year $i$, then it will be operated for $(j-i)$ years and the expenses associated with this decision are possible to calculate by the following formula:

$$
s_{i j}=p_{j}-v_{j-i}+\left(r_{1}+r_{2}+\ldots+r_{j-i}\right) .
$$

Let the given data be in Table 4 . 


\section{Управление в социально-экономических системах}

Given data to devise a replacement plan

\begin{tabular}{|l|c|c|c|c|c|c|c|}
\hline & 1 & 2 & 3 & 4 & 5 & 6 & 7 \\
\hline$p_{t}$ & 100 & 105 & 110 & 115 & 120 & 125 & 130 \\
\hline$r_{k}$ & 30 & 40 & 50 & 50 & 60 & 70 & 100 \\
\hline$v_{k}$ & 50 & 25 & 10 & 5 & 2 & 1 & 0 \\
\hline
\end{tabular}

Let's calculate $s_{i j}$ by formula (6) and put the results in Table 5 .

Table 5

Values of $s_{i j}$ coefficients

\begin{tabular}{|c|c|c|c|c|c|c|c|}
\hline$s_{i j}$ & 2 & 3 & 4 & 5 & 6 & 7 & 8 \\
\hline 1 & $\begin{array}{l}105-50+30= \\
=85\end{array}$ & $\begin{array}{l}110-25+70= \\
=155\end{array}$ & $\begin{array}{l}115-10+120= \\
=225\end{array}$ & $\begin{array}{l}120-5+170= \\
=285\end{array}$ & $\begin{array}{l}125-2+230= \\
=353\end{array}$ & $\begin{array}{l}130-1+300= \\
=429\end{array}$ & $\begin{array}{l}0+400= \\
=400\end{array}$ \\
\hline 2 & & $\begin{array}{l}110-50+30= \\
=90\end{array}$ & $\begin{array}{l}115-25+70= \\
=160\end{array}$ & $\begin{array}{l}120-10+20= \\
=230\end{array}$ & $\begin{array}{l}125-5+170= \\
=290\end{array}$ & $\begin{array}{l}130-2+230= \\
=358\end{array}$ & $\begin{array}{l}-1+300= \\
=299\end{array}$ \\
\hline 3 & & & $\begin{array}{l}115-50+30= \\
=95\end{array}$ & $\begin{array}{l}120-25+70= \\
=165\end{array}$ & $\begin{array}{l}125-10+120= \\
=235\end{array}$ & $\begin{array}{l}130-5+170= \\
=295\end{array}$ & $\begin{array}{l}-2+230= \\
=228\end{array}$ \\
\hline 4 & & & & $\begin{array}{l}120-50+30= \\
=100\end{array}$ & $\begin{array}{l}125-25+70= \\
=170\end{array}$ & $\begin{array}{l}130-10+120= \\
=240\end{array}$ & $\begin{array}{l}-5+170= \\
=165\end{array}$ \\
\hline 5 & & & & & $\begin{array}{l}125-50+30= \\
=105\end{array}$ & $\begin{array}{l}130-25+70= \\
=175\end{array}$ & $\begin{array}{l}- \\
10+120= \\
=110\end{array}$ \\
\hline 6 & & & & & & $\begin{array}{l}130-50+30= \\
=110\end{array}$ & $\begin{array}{l}-25+70= \\
=45\end{array}$ \\
\hline 7 & & & & & & & $\begin{array}{l}-50+30= \\
=20\end{array}$ \\
\hline
\end{tabular}

Calculating the expenses in column 8 we consider the fact that the new machine tool is not purchased any more at the beginning of year 8 , there is no need for it under the terms of our example.

To find the optimum plan of replacements we shall use the algorithm of finding the shortest way again.

$$
\begin{aligned}
& y_{8}=0, \\
& y_{7}=\min \left\{s_{78}+y_{8}\right\}=(-20+0)=-20, \\
& y_{6}=\min \left\{s_{67}+y_{7}, s_{68}+y_{8}\right\}=\min \{110-20,45+0\}=45, \\
& y_{5}=\min \left\{s_{56}+y_{6}, s_{57}+y_{7}, s_{58}+y_{8}\right\}=\min \{105+45,175-20,110+0\}=110, \\
& y_{4}=\min \left\{s_{45}+y_{5}, s_{46}+y_{6}, s_{47}+y_{7}, s_{48}+y_{8}\right\}= \\
& =\min \{100+110,170+45,240-20,165\}=165, \\
& y_{3}=\min \left\{s_{34}+y_{4}, s_{35}+y_{5}, s_{36}+y_{6}, s_{37}+y_{7}, s_{38}+y_{8}\right\}= \\
& =\min \{95+165,165+110,235+45,295-20,228\}=228, \\
& y_{2}=\min \left\{s_{23}+y_{3}, s_{24}+y_{4}, s_{25}+y_{5}, s_{26}+y_{6}, s_{27}+y_{7}, s_{28}+y_{8}\right\}= \\
& =\min \{90+228,160+165,230+110,290+45,358-20,299\}=299, \\
& y_{1}=\min \left\{s_{12}+y_{2}, s_{13}+y_{3}, s_{14}+y_{4}, s_{15}+y_{5}, s_{16}+y_{6}, s_{17}+y_{7}, s_{18}+y_{8}\right\}= \\
& =\min \{85+299,155+228,225+165,285+110,353+45,429-20,400\}=383 .
\end{aligned}
$$

We have received the shortest way (1-3-8) which corresponds to the following optimum strategy: the machine tool bought at the beginning of year 1 needs to be replaced at the beginning of year 3 and operate it until the end of the considered period (the remained 5 years), at the same time the expenses will be minimum and equal 383 (without the cost of the machine tool purchased in the first year). 


\subsection{Algorithm of dynamic programming}

It is possible to use algorithms of dynamic programming when modelling a problem of replacement of equipment (see [12-15]).

Let value $s_{i j}$ be the sum of expenses and expected maintenance costs of the equipment which is purchased at the beginning of year $i$, minus the salvage cost of the equipment as at the beginning of year $j$.

Let $y_{i}$ be the value of expenses which is reached at the strategy of the replacement providing the minimum of these expenses in intervals $i, i+1, \ldots, n$ if the new equipment is bought in year $i$.

Then finding the optimum strategy comes down to calculating $y_{1}$ and the corresponding strategy of the first step. At the same time the following recurrence equations are used:

$$
\begin{gathered}
y_{n+1}=0, \\
y_{i}=\min _{j>i}\left\{s_{i j}+y_{j}\right\}, i=n, n-1, \ldots, 1 .
\end{gathered}
$$

It is obvious that finding the optimum strategy in a multistep process using equation (7) coincides greatly with the algorithm of finding the shortest way in an acyclic network.

The problem of replacement of equipment by means of dynamic programming can be simulated in a bit different way.

Let the expenses corresponding with the strategy of replacement include two components:

$c_{i m}$ is costs of replacement of equipment of age $m$ in interval $i$ minus salvage cost;

$r_{i m}$ is operational costs of the equipment of age $m$ in interval $i$.

Let $y_{i}(m)$ be the strategy at which the minimum expenses on intervals $i, i+1, \ldots, n$ is reached, if the age of the equipment at the beginning of interval $i$ is $m$ years.

At keeping the equipment in interval $i$ an optimal solution is

$y_{i}(m)=r_{i m+1}+y_{i+1}(m+1)$,

but at an optimal decision connected with its replacement

$y_{i}(m)=c_{i m}+r_{i 1}+y_{i+1}(1)$.

We shall receive

$y_{i}(m)=\min \left\{r_{i m+1}+y_{i+1}(m+1), c_{i m}+r_{i 1}+y_{i+1}(1)\right\}, i=1,2, \ldots, n$,

where $y_{n+1}(m)=0$ for all $m$.

Let $M$ be a possible operating life of the equipment. We are devising a plan for $\mathrm{n}$ years, therefore the beginning of $(n+1)$ period is the end of the planned period.

To find an optimal solution $y_{1}\left(m_{0}\right)$ is calculated, where $m_{0}$ is the age of the equipment as at the beginning of the period. If at the beginning some equipment is absent, the decision on replacement at $i=1$ is its purchase.

Example 5. Let us devise a plan of replacement of the equipment for five years purchased at the beginning of year 1. The predicted expenses are given in Tables 6 and 7.

Table 6

Table 7

Values of $r_{i m}$

Values of $c_{i m}$

\begin{tabular}{|c|c|c|c|c|c|}
\hline$r_{\text {im }}$ & 1 & 2 & 3 & 4 & 5 \\
\hline 1 & 10 & & & & \\
\hline 2 & 8 & 16 & & & \\
\hline 3 & 6 & 12 & 18 & & \\
\hline 4 & 4 & 8 & 12 & 20 & \\
\hline 5 & 0 & 0 & 10 & 15 & 20 \\
\hline
\end{tabular}

\begin{tabular}{|c|c|c|c|c|}
\hline$c_{i m}$ & 1 & 2 & 3 & 4 \\
\hline 1 & 100 & & & \\
\hline 2 & 55 & & & \\
\hline 3 & 60 & 80 & & \\
\hline 4 & 65 & 85 & 105 & \\
\hline 5 & 70 & 90 & 110 & 115 \\
\hline
\end{tabular}

Empty cells in the tables mean that there is no equipment at the beginning of the planned period therefore there are no expenses, for example, in the third year there is no 4-year equipment and there is no 5-year-old equipment in any year due to which column 5 is absent in Table 7.

Let's use recurrence equation (8): $y_{6}(m)=0$ for all $m$. 
$i=5$ (at the beginning of the fifth year, the age of the equipment is less than 5):

$$
\begin{aligned}
& y_{5}(4)=\min \left\{r_{55}+y_{6}(5), c_{54}+r_{51}+y_{6}(1)\right\}=\min \{200+0,115+10+0\}=125, \\
& y_{5}(3)=\min \left\{r_{54}+y_{6}(4), c_{53}+r_{51}+y_{6}(1)\right\}=\min \{85+0,110+10+0\}=85, \\
& y_{5}(2)=\min \left\{r_{53}+y_{6}(3), c_{52}+r_{51}+y_{6}(1)\right\}=\min \{40+0,90+10+0\}=40, \\
& y_{5}(1)=\min \left\{r_{52}+y_{6}(2), c_{51}+r_{51}+y_{6}(1)\right\}=\min \{20+0,70+10+0\}=20 .
\end{aligned}
$$

$i=4$ (at the beginning of the fourth year, the age is no more than 3 ):

$$
\begin{aligned}
& y_{4}(3)=\min \left\{r_{44}+y_{5}(4), c_{43}+r_{41}+y_{5}(1)\right\}=\min \{120+125,105+14+20\}=139, \\
& y_{4}(2)=\min \left\{r_{43}+y_{5}(3), c_{42}+r_{41}+y_{5}(1)\right\}=\min \{52+85,85+14+20\}=119, \\
& y_{4}(1)=\min \left\{r_{42}+y_{5}(2), c_{41}+r_{41}+y_{5}(1)\right\}=\min \{28+40,65+14+20\}=68 .
\end{aligned}
$$

$i=3$ (at the beginning of the third year, the age is no more than 2):

$y_{3}(2)=\operatorname{in}\left\{r_{33}+y_{4}(3), c_{32}+r_{31}+y_{4}(1)\right\}=\min \{68+139,80+16+68\}=164$,

$y_{3}(1)=\min \left\{r_{32}+y_{4}(2), c_{31}+r_{31}+y_{4}(1)\right\}=\min \{32+119,60+16+68\}=144$.

$i=2$ (at the beginning of the second year, the age is no more than 1):

$y_{2}(1)=\min \left\{r_{22}+y_{3}(2), c_{21}+r_{21}+y_{3}(1)\right\}=\min \{36+164,55+18+144\}=200$.

As the new equipment is purchased at the beginning of year 1 under the condition of the example, $y_{1}(0)=c_{11}+r_{11}+y_{2}(1)=100+20+200=320$.

We have received the optimal strategy which consists in the following: in the 3rd year we replace the equipment purchased at the beginning of year 1 and we use it until the end of the 5 th year.

\section{Stochastic models of replacement of the equipment}

\subsection{Stochastic model with a limited planned period}

Above we have examined some deterministic tasks of replacement of equipment, where index $\mathrm{m}$ reflected the duration of normally operated equipment. We shall further consider a stochastic version of problem of reconditioning where breakage of the device before the planned replacement term is allowed (in this case it is replaced in the timepoint following breakage).

We shall set $p_{j}$ as probability of breakage of the equipment at moment $j$ of its operation $(j<m)$;

$r_{j}$ is operational costs of the properly functioning equipment in interval $j$ of its use;

$g_{j}$ is additional expenses caused by premature breakage of the equipment in interval $j$.

Let initial expenses $r_{1}$ include the initial cost of the equipment and the out-of-order devices are completely depreciated (for example, burned-down electric motors, lamps, etc.).

The optimal strategy will consist in minimization of mathematical expectation of the expenses which consider:

- average expenses on reconditioning at the breakage of the equipment before planned moment $m$;

- average expenses on reconditioning in cases of breakage of the equipment before planned moment $m$;

- the expected operational costs during the period from the reconditioning till the next moment of reconditioning.

Thus, generalizing relations (7) and (8), we receive

$$
y_{i}=\min _{m=1, \ldots, M}\left\{\sum_{j=1}^{m-1} y_{i+j} p_{j}+y_{i+m}\left(1-\sum_{j=1}^{m-1} p_{j}\right)+R_{m}\right\}, i=1, \ldots, n, y_{n+1}=0,
$$

where the first sum is mathematical expectation of expenses on premature replacement, the addend is product of minimum expenses from period $i+m$ onwards and probabilities of normal operation of the equipment till this period. The third compound reflects the operational costs calculated by the following formula:

$$
R_{m}=r_{1}+r_{2}\left(1-p_{1}\right)+r_{3}\left(1-p_{1}-p_{2}\right)+\ldots+r_{m}\left(1-\sum_{j=1}^{m-1} p_{j}\right)+\sum_{j=1}^{m-1} g_{j} p_{j} .
$$


These expenses are made up of the expenses of year 1 of use of the equipment plus the expenses of year 2 multiplied by probability of its non-breakage in year 1 plus the expenses of year 3 multiplied by probability of its non-breakage in the first two years, etc. till interval $m$ plus mathematical expectation of expenses on repair at premature breakage till interval $m$.

\subsection{Stochastic model with unlimited planned period}

Now we shall consider a stochastic problem of replacement of the equipment at an unlimited planned period.

Let us assume that in this case the optimal strategy is time constant (i.e. replacement is made constantly at time interval $m$ ). Then the formula to define the optimal strategy becomes significantly simpler:

$$
y=\min _{m=1,2, \ldots, M}\left\{R_{m} / E_{m}\right\},
$$

where $E_{m}$ is mathematical expectation of replacement age of the equipment

$$
E_{m}=\sum_{j=1}^{m-1} j p_{j}+m\left(1-\sum_{j=1}^{m-1} p_{j}\right) .
$$

The equation in the braces in (11) defines the expected expenses for one interval of the planned period which coincides with the technique to define the optimal strategy examined by us in example 1 . Table 8 .

Example 6. The given data for the first 5 years of the unlimited planned period are presented in

Given data for the first $\mathbf{5}$ years of the unlimited planned period

Table 8

\begin{tabular}{|c|c|c|c|c|c|c|}
\hline$m$ & $p_{m}$ & $r_{m}$ & $g_{m}$ & $R_{m}$ & $E_{m}$ & $R_{m} / E_{m}$ \\
1 & 2 & 3 & 4 & 5 & 6 & 7 \\
\hline 1 & $1 / 4$ & 100 & 20 & 100 & 1 & 100 \\
\hline 2 & 0 & 7 & 60 & 114 & 1,75 & 65,14 \\
\hline 3 & $1 / 4$ & 20 & 180 & 129 & 2,5 & 51,6 \\
\hline 4 & 0 & 20 & 200 & 184 & 3 & 61,33 \\
\hline 5 & $1 / 2$ & 56 & 200 & 212 & 3,5 & 60,57 \\
\hline
\end{tabular}

The values in column 5 are calculated by formula (10):

$R_{1}=r_{1}=100$,

$R_{2}=r_{1}+r_{2}\left(1-p_{1}\right)+g_{1} p_{1}=100+12 \cdot \frac{3}{4}+20 \cdot \frac{1}{4}=114$,

$R_{3}=r_{1}+r_{2}\left(1-p_{1}\right)+r_{3}\left(1-p_{1}-p_{2}\right)+g_{1} p_{1}+g_{2} p_{2}=114+20 \cdot \frac{3}{4}=129$,

$R_{4}=129+20 \cdot \frac{1}{2}+180 \cdot \frac{1}{4}=184$,

$R_{5}=184+56 \cdot \frac{1}{2}=212$.

The values in column 6 are calculated by formula (12):

$E_{1}=1$,

$E_{2}=1 \cdot p_{1}+2\left(1-p_{1}\right)=\frac{1}{4}+2 \cdot \frac{3}{4}=1.75$,

$E_{3}=1 \cdot p_{1}+2 \cdot p_{2}+3\left(1-p_{1}-p_{2}\right)=\frac{1}{4}+2 \cdot 0+3 \cdot \frac{3}{4}=2.5$,

$E_{4}=1 \cdot p_{1}+2 \cdot p_{2}+3 \cdot p_{3}+4\left(1-p_{1}-p_{3}\right)=\frac{1}{4}+\frac{3}{4}+4 \cdot \frac{1}{2}=3$,

$E_{5}=1 \cdot p_{1}+2 \cdot p_{2}+3 \cdot p_{3}+4 \cdot p_{4}+5 \cdot \frac{1}{2}=\frac{1}{4}+\frac{3}{4}+5 \cdot \frac{1}{2}=3.5$. 


\section{Управление в социально-экономических системах}

We shall find a relation minimum in column 7 at $m=3$, it will be the optimal planned term of replacement of the equipment.

The received result shows how important it is to account a factor of uncertainty. In these examples the expected expenses at one interval are almost $20 \%$ more than the optimal value.

\subsection{Stochastic models in consideration of discounting}

If we also consider the discounting coefficient (let $i$ be an interest rate in each period and $d=1 /(1+i / 100))$, formulas (9)-(10) will be as follows:

$$
\begin{aligned}
& y_{i}=\min _{m=1, \ldots, M}\left\{\sum_{j=1}^{m-1} d^{j} y_{i+j} p_{j}+d^{m} y_{i+m}\left(1-\sum_{j=1}^{m-1} p_{j}\right)+R_{m}\right\}, i=1, \ldots, n, y_{n+1}=0, \\
& R_{m}=r_{1}+d^{1} r_{2}\left(1-p_{1}\right)+d^{2} r_{3}\left(1-p_{1}-p_{2}\right)+\ldots+d^{m-1} r_{m}\left(1-\sum_{j=1}^{m-1} p_{j}\right)+\sum_{j=1}^{m-1} d^{j-1} g_{j} p_{j} .
\end{aligned}
$$

\section{Conclusion}

In this article mathematical models of problems of replacement and wearing of equipment at the determined and stochastic information for a limited and unlimited period are considered. In the examples a year is used as the increment of time, although the given algorithms can be used for monthly planning as well as for decade planning. At the same time the dimension of the problem will significantly increase, but at today's computer capacities it won't cause any trouble with realization of these algorithms on the computer.

\section{References}

1. Pelikh A.S., Terekhov L.L., Terekhova L.A. Ekonomiko-matematicheskie metody $i$ modeli upravleniya proizvodstvom [Economic and Mathematical Methods and Models of Production Management]. Rostov-on-Don, Phoenix Publ., 2005. 256 p.

2. Pervozvanskiy A.A. Matematicheskie modeli v upravlenii proizvodstvom [Mathematical Models in Production Management]. Moscow, Nauka Publ., 1975. 616 p.

3. Venttsel' E.S. Issledovanie operatsiy. Zadachi, printsipy, metodologiya [Operations Research: Problems, Principles, Methodology. Moscow, Yustitsia Publ., 2018. 192 p.

4. Brodetskiy G.L. Ekonomiko-matematicheskie metody i modeli v logistike: potoki sobytiy i sistem obsluzhivaniya [Economic and Mathematical Methods and Models in Logistics: Flows of Events and Service Systems]. Moscow, ITS Academia Publ., 2011. 272 p.

5. Getmanchuk A.V. Ekonomiko-matematicheskie metody i modeli [Economic and Mathematical Methods and Models]. Moscow, Dashkov and Co Publ., 2015. 188 p.

6. Glukhov V.V., Mednikov M.D., Korobko S.B. Matematicheskie metody i modeli dlya menedzhmenta. Uchebnik [Mathematical Methods and Models for Management: Textbook]. Saint Petersburg, Lan' Publ., 2000. 480 p.

7. Troyanovsky V.M. Matematicheskoe modelirovanie v menedzhmente. Uchebnoe posobie [Mathematical Modeling in Management: Study Guide]. Moscow, Russkaya Delovaya Literatura Publ., 2003. $256 \mathrm{p}$.

8. Shikin E.V., Chkhartishvilli A.G. Matematicheskie metody i modeli v upravlenii [Mathematical Methods and Models in Management]. Moscow, Delo Publ., 2004. 44 p.

9. Vasil'ev S.N., Matrosov V.M., Moskalenko A.I. Nelineynaya teoriya upravleniya $i$ ee prilozheniya [Non-linear Theory of Management and its Applications]. Moscow, FML Publ., 2008. $320 \mathrm{p}$.

10. Krasnoschekov P.S., Petrov A.A. Printsipy postroeniya modeley [Design Concept of Models]. Moscow, Fasis Publ., 2000. 424 p.

11. Samarskiy A.A., Mikhailov A.P. Matematicheskoe modelirovanie: Idei, metody, primery [Mathe-matical Modeling: Ideas, Methods, Examples]. Moscow, Phismathlit Publ., 2005. 320 p.

12. Takha Hamdy A. Vvedenie v issledovanie operatsiy [An Introduction to Operations Re-search]. Moscow, Williams Publ. House, 2016. 912 p.

13. Bellman R. Dynamic Programming. New York, Mineola, Dover Publications, Inc., 2013. 366 p. 
14. Denardo E.V. Dynamic Programming: Models and Applications. New York, Mineola, Dover Publications, Inc., 2012. 240 p.

15. Bertsekas D.P. Dynamic Programming and Optimal Control. Belmont, Massachusetts, Athena Scientific, 2012. 1270 p.

Received 15 February 2018

УДК 519.873

DOI: $10.14529 /$ ctcr180212

\title{
МАТЕМАТИЧЕСКИЕ МОДЕЛИ ЗАМЕНЫ И ИЗНОСА ОБОРУДОВАНИЯ
}

\author{
Я.Д. Гельруд, А.В. Голлай \\ Южно-Уральский государственный университет, г. Челябинск, Россия
}

\begin{abstract}
При управлении промышленным производством одной из важнейших проблем является решение вопросов эффективного использования оборудования. Текущий и капитальный ремонт оборудования, его замена связаны с большими материальными, трудовыми и финансовыми затратами. Кроме того, простои оборудования существенным образом влияют на эффективность промышленного производства в целом. В статье описаны математические модели задач замены оборудования при детерминированной и стохастической информации для конечного и неограниченного периода. Приведена модель замены оборудования, использующая язык сетевого моделирования, также при моделировании задачи замены оборудования использованы алгоритмы динамического программирования. На основе предложенных моделей строится обобщающий алгоритм решения задачи замены оборудования. Также показана важность учёта фактора неопределенности при решении задач данного класса. Полученные результаты могут быть использованы при построении оптимальной стратегии замены оборудования на промышленном предприятии.

Ключевые слова: оборудование, замена оборудования, инвестиции, инвестиционная политика, динамическое программирование, стратегия.
\end{abstract}

\section{Литература}

1. Пелих, А.С. Экономико-математические методы и модели управления производством / А.С. Пелих, Л.Л. Терехов, Л.А. Терехова. - Ростов н/Д.: Феникс, 2005. - 256 с.

2. Первозванский, А.А. Математические модели в управлении производством / А.А. Первозванский. - М.: Наука, 1975. - 616 с.

3. Вентиель, Е.С. Исследование операций. Задачи, принцииы, методология / Е. С. Вентиель. М.: Юстиция, 2018. - 192 c.

4. Бродеикий, Г.Л. Экономико-математические методы и модели в логистике: потоки событий и систем обслуживания / Г.Л. Бродеикий. - М.: ИЦ Академия, 2011. - 272 c.

5. Гетманчук, А.В. Экономико-математические методы и модели / А.В. Гетманчук. - М.: Дашков и К, 2015. - $188 \mathrm{c}$.

6. Глухов, В.В. Математические методы и модели для менеджмента: учеб. / В.В. Глухов, М.Д. Медников, С.Б. Коробко. - СПб.: Лань, 2000. - 480 с.

7. Трояновский, В.М. Математическое моделирование в менеджменте: учеб. пособие / В.М. Трояновский. - М.: Русская Деловая Литература, 2003. - 256 с.

8. Шикин, Е.В. Математические методы и модели в управлении / Е.В. Шикин, А.Г. Чхартишвили. - М.: Дело, 2004. - 440 с.

9. Васильев, С.Н. Нелинейная теория управления и ее приложения / С.Н. Васильев, В.М. Матросов, А.И. Москаленко. - М.: ФМЛ, 2008. - 320 с. 


\section{Управление в социально-экономических системах}

10. Краснощеков, П.С. Принцииь построения моделей / П.С. Краснощеков, А.А. Петров. М.: Фазис, 2000. - 424 c.

11. Самарский, А.А. Математическое моделирование: Идеи, методы, примеры / А.А. Самарский, А.П. Михайлов. - М.: Физматлит, 2005. - 320 с.

12. Таха, Х.А. Введение в исследование операщий: пер. с анл. / Х.А. Таха. - 8-е изд. - М.: Издат. дом «Вильямс», 2016. - 912 с.

13. Bellman, R. Dynamic Programming / R. Bellman. - Mineola, New York: Dover Publications, Inc., 2013. $-366 c$.

14. Denardo, E.V. Dynamic Programming: Models and Applications / E.V. Denardo. - Mineola, New York: Dover Publications, Inc., 2012. - 240 p.

15. Bertsekas, D.P. Dynamic Programming and Optimal Control / D.P. Bertsekas. - Belmont, Massachusetts: Athena Scientific, 2012. -1270 p.

Гельруд Яков Давидович, д-р техн. наук, профессор кафедры экономики и управления на предприятиях строительства и землеустройства Высшей школы экономики и управления, ЮжноУральский государственный университет, г. Челябинск; gelrud@mail.ru.

Голлай Александр Владимирович, канд. хим. наук, доцент кафедры экономики и управления на предприятиях строительства и землеустройства Высшей школы экономики и управления, Южно-Уральский государственный университет, г. Челябинск; alexander@hollay.ru.

Поступила в редакцию 15 февраля 2018 г.

\section{ОБРАЗЕЦ ЦИТИРОВАНИЯ}

Gelrud, Ya.D. Mathematical Models of Replacement and Wearing of Equipment / Ya.D. Gelrud, A.V. Gollay // Вестник ЮУрГУ. Серия «Компьютерные технологии, управление, радиоэлектроника». - 2018. - Т. 18, № 2. C. $121-130$. DOI: $10.14529 /$ ctcr 180212

\section{FOR CITATION}

Gelrud Ya.D., Gollay A.V. Mathematical Models of Replacement and Wearing of Equipment. Bulletin of the South Ural State University. Ser. Computer Technologies, Automatic Control, Radio Electronics, 2018, vol. 18 , no. 2 , pp. 121-130. DOI: $10.14529 /$ ctcr180212 